\title{
PROGRAM PEMBELAJARAN SECARA DARING BAGI GURU, KEPALA SEKOLAH, ORANG TUA DAN SISWA MELALUI SERVICE LEARNING UPH PADA MASA PANDEMI COVID-19
}

\author{
Wiputra Cendana ${ }^{1}$, Grace Solarbesain ${ }^{2}$, Hernawati Siahaan ${ }^{3}$ \\ ${ }^{1}$ Universitas Pelita Harapan \\ ${ }^{2}$ Universitas Pelita Harapan \\ ${ }^{3}$ Universitas Pelita Harapan
}

wiputra.cendana@uph.edu,grace.solarbesin@uph.edu, hernawati.siahaan@uph.edu

\begin{abstract}
Abstrak
Lokasi Yayasan Shine Tiara Veritas sebagai mitra Pengabdian kepada Masyarakat (PkM) ini terletak di daerah Kecamatan Cikande, Kabupaten Serang sekitar 43KM dari kampus UPH Karawaci. Yayasan ini memiliki kepedulian yang tinggi dalam meningkatkan kualitas pembelajaran bekerja sama dengan Teachers College dan Service Learning UPH sejak 2018 dalam bentuk seminar. Kemudian, kegiatan diubah menjadi pembelajaran daring dalam bentuk webinar melalui aplikasi zoom meeting di tengah pandemic Covid-19 dari dosen-dosen Fakultas Pendidikan UPH untuk memberikan pemahaman terkait pengembangan kompetensi guru era digital di Indonesia. Metode pelaksanaan disajikan dalam bentuk 5 kali webinar dengan 2 sesi dan 2 materi per satu kali webinar. Peserta webinar adalah guru, kepala sekolah, dan orang tua se-Jabodetabek maupun se-Nusantara berdasarkan jejaring media sosial yang dimiliki. Target peserta \pm 150 sd 200 peserta per webinar. Akhir dari kegiatan Pengabdian kepada Masyarakat (PkM) adalah menyediakan buku-buku cerita, rak buku, alat edukasi/media permainan untuk melengkapi sarana perpustakaan sekolah yang dijadikan pojok baca anak-anak sekitar sekolah.
\end{abstract}

Kata kunci : kepedulian, kompetensi, pembelajaran

\section{PENDAHULUAN}

Yayasan Shine Tiara Veritas sebagai mitra Pengabdian Kepada Masyarakat (PKM) yang memberikan pelayanan sekolah gratis untuk usia dini melalui program Service Learning Project. Kegiatan dimulai sejak 2018 dengan bentuk renovasi sekolah PAUD / TK seperti pengecatan, menghias maupun mendesain ruangan kelas, membuat ide-ide kegiatan pembelajaran menarik dan kegiatan open house sekolah dengan perlombaan menarik. Kemudian dilanjutkan dengan adanya program kakak asuh untuk membantu siswa bisa mendapatkan pembelajaran gratis dan membantu biaya operasional sekolah untuk bisa bertahan sampai saat ini.

Selain itu, Yayasan Shine Tiara Veritas memiliki kepedulian yang tinggi dalam meningkatkan kualitas pembelajaran dengan memberikan edukasi bagi para guru, kepala sekolah dan orangtua bekerja sama dengan Service Learning UPH sejak 2018. Kegiatan yang pernah dilakukan sebelumnya berupa seminar pendidikan secara berkelanjutan bagi tenaga pendidik se-Jabodetabek sampai dengan saat ini. Untuk melanjutkan program ini dan menyesuaikan dengan situasi pandemi 
Covid-19, maka kegiatan diubah menjadi pembelajaran daring dalam bentuk webinar dengan memanfaatkan kecanggihan aplikasi online meeting di masa pandemi ini. Kelebihan penggunaan teknologi informasi dan komunikasi dalam pelaksanaan pembelajaran daring diantaranya adalah tidak terikat ruang dan waktu (Pangondian, R. A., Santosa, P. I., \& Nugroho, E, 2019). Dengan demikian, pendidik tetap bisa mengembangkan diri melalui materi pembelajaran webinar yang disajikan.

Proses pembelajaran selama ini masih didominasi oleh guru sehingga belum memberikan kesempatan bagi siswa untuk berkembang secara mandiri melalui penemuan dan proses berpikir. Cara guru mengajar yang hanya satu arah (teacher centered) menyebabkan penumpukan informasi atau konsep saja yang kurang bermanfaat bagi siswa. (Setyotini, Sukswo, 2011, h. 52). Mengacu pada pembelajaran seperti diungkapkan di atas diperlukan upaya agar pembelajaran mengarah kepada interaktif dan bersifat dua arah. Selain itu juga kurangnya interaksi antara guru dengan siswa yang menyebabkan adanya ketidakhormonisan pada saat pembelajaran berlangsung sehingga suasana kelas menjadi kurang menarik dan cenderung membosankan. (Kusmaryono \& Setiawati, 2013, h. 140). Mengacu kepada evaluasi proses pembelajaran ini, tim peneliti melakukan persiapan dalam memfasilitasi tantangan dan kebutuhan yang ada.

Lebih dari itu, yayasan terus berjuang memperlengkapi kebutuhan belajar anak usia dini dengan memberikan informasi permasalahan lembaga melalui pertemuan mitra yang secara rutin dilakukan Service Learning Division UPH. Berdasarkan hasil diskusi, permasalahan yang dialami mitra antara lain; 1). adanya keinginan dan rasa kepedulian untuk meningkatkan kualitas pembelajaran dengan memberikan edukasi bagi para guru, kepala sekolah dan orangtua, 2). adanya kebutuhan pembelajaran siswa yang belum terpenuhi yaitu perpustakaan sebagai sarana pojok baca berupa penyediaan buku-buku bacaan dan kelengkapan sarana lainnya dikarenakan kurangnya panduan materi pembelajaran melalui aplikasi online dikarenakan keterbatasan siswa memiliki HP dan aplikasi online meeting,. Hal ini seturut denga napa yang disampaikan Kreativitas guru adalah kemampuan guru menciptakan hal-hal baru dalam mengajar sehingga memiliki variasi didalam mengajar yang akan membuat anak didik lebih aktif dan kreatif. (Yanti, 2020, h. 810)

Untuk mengembangkan program di atas, Service Learning UPH bekerja sama dengan beberapa dosen Fakultas Ilmu Pendidikan melalui Pengabdian Kepada Masyarakat (PKM) ini untuk menjawab permasalahan mitra. Kegiatan yang dilakukan dengan kegiatan webinar berisi materi menarik dan bermanfaat berupa "PROGRAM PEMBELAJARAN SECARA DARING BAGI GURU, KEPALA SEKOLAH, ORANG TUA DAN SISWA MELALUI SERVICE LEARNING UPH PADA MASA PANDEMI COVID-19" untuk membangun pendidikan usia dini di Indonesia. Kegiatan berikutnya berupa materi pembelajaran bagi siswa sekaligus anak-anak usia dini di sekitarnya dilakukan secara luring dengan membuat pojok baca siswa. Hal ini dikarenakan tidak semua siswa memiliki HP untuk proses pembelajaran secara daring, maka sekolah masih memberlakukan adanya kelas tatap muka dengan prasyarat utama untuk kesediaan menjaga jarak namun tetap menciptakan suasana baca yang nyaman, buku-buku terbaru yang berbeda dan sarana belajar yang menyenangkan.

Metode pelaksanaan program pembelajaran secara daring disajikan dalam bentuk 5 kali webinar dengan 2 sesi dan 2 materi per satu kali webinar. Peserta webinar adalah guru, kepala sekolah, dan orang tua. Webinar dilakukan dengan bekerja sama antara Service Learning UPH dan Yayasan Shine Tiara Veritas. Kemudian, Yayasan ini akan mempublikasikan acara dan mengajak relasi guruguru PAUD / TK maupun SD se-Jabodetabek maupun se-Nusantara berdasarkan jejaring media sosial yang dimiliki. Target peserta $\pm 150-200$ peserta per webinar. Panitia acara juga melakukan evaluasi webinar melalui tanya jawab secara online kepada peserta dalam pengembangan program selanjutnya.

\section{METODE}

Metode yang digunakan adalah metode deskriptif. Metode ini menggambarkan suatu 
metode dalam meneliti status sekelompok manusia, suatu objek, suatu set kondisi, suatu sistem pemikiran, ataupun suatu kelas peristiwa pada masa sekarang (Moh. Nazir, 2011: 54). Tujuan metode ini untuk memberikan gambaran atau deskripsi atau lukisan secara sistematis, faktual, dan akurat mengenai fakta-fakta, sifat-sifat dan hubungan antara fenomena yang diselidiki. Teknik pengumpulan data melalui wawancara, dokumentasi dan studi pustaka. Pelaksanaan rangkaian kegiatan dilakukan periode April sampai dengan Agustus 2021.

Prosedur pelaksanaan kegiatan ini diawali melakukan survey terlebih dahulu terhadap materi apa yang dibutuhkan melalui webinar. Survey diberikan kepada mitra Service Learning UPH dan pendidik umum lainnya melalui media sosial. Setelah itu, panitia inti mulai melakukan pemetaan teknis kegiatan webinar. Langkah selanjutnya, mencari serta membentuk panitia yang terdiri dari 7-8 orang per satu webinar. Setelah terbentuk panitia, dilakukan briefing dan pembagian jobdesc bagi setiap panitia, seperti mencari sekaligus menghubungi pembicara yang berkompeten di bidangnya, menyusun undangan pembicara, menyususn rundown, mendesain e'poster, menyebar undangan melalui media sosial dan group komunikasi bersama peserta dengan memanfaatkan aplikasi handphone. Proses persiapan yang dilakukan panitia dilakukan selama 2 minggu dan dilanjutkan dengan pelaksanaan webinar sesuai tanggal-tanggal yang sudah ditentukan. Setelah pelaksanaan acara, dilakukan evaluasi, pembagian e'sertifikat dan materi webinar bagi peserta yang hadir dan pembuatan Laporan Pertanggungjawaban (LPJ) oleh panitia.

\section{HASIL DAN PEMBAHASAN}

Webinar pertama dilaksanakan pada hari Sabtu, 24 April 2021 pukul 10.00 - 12.00 WIB dengan judul "Mengembangkan Kompetensi Kepribadian Guru Melalui Perencanaan Keuangan Keluarga Indonesia (PK2I)". Webinar ini dihadiri oleh sekitar 148 peserta. Inti dari pembahasan webinar pertama ini yaitu tentang pengembengan kompetensi kepribadian guru melalui edukasi sederhana dalam menyelesaikan persoalan keuangan yang dihadapi oleh pendidik dengan adanya perencanaan keuangan keluarga yang baik. Oleh karena itu, disajikan pemaparan teori tentang manajemen keuangan sederhana dan inovatif serta solusi yang aplikatif untuk secara konsisten dijalankan sekaligus beberapa cara menambah pendapatan rumah tangga diluar pekerjaan utama pendidik tanpa mempengaruhi KPI (Key Performance Indicators) pendidik. Berdasarkan hasil evaluasi dari setiap peserta, diperoleh presentase sebanyak $75.6 \%$ dari peserta merasa bahwa program webinar sudah tepat sasaran, $82.1 \%$ dari peserta berpendapat bahwa isi materi webinar yang diterima peserta sudah sangat baik, $84.6 \%$ dari peserta menyatakan bahwa pembicara telah menguasai dan menyampaikan materi yang dibawakan dengan sangat baik, sebanyak $74.7 \%$ peserta juga menyatakan bahwa pembicara dapat menyampaikan materinya dengan melakukan pendekatan teori, serta solusi yang relevan dan aplikatif terhadap peserta. $76.3 \%$ dari peserta juga memberikan feedback akan mengaplikasikan setiap materi ke dalam kehidupan sehari-hari. Selain itu, sebanyak $72.4 \%$ dari peserta setuju bahwa Moderator dan MC dapat memandu jalannya webinar dengan baik, serta setiap panitia dapat mempersiapkan webinar ini dengan baik. Dengan demikian, webinar pertama berjalan dengan baik dan menjawab solusi permasalahan mitra.

Webinar kedua dilaksanakan pada hari Sabtu, 1 Mei 2021 pukul 10.00 - 12.00 WIB dengan judul "Digital Citizenship for Educators" yang bertujuan untuk mengedukasi para penggiat pendidikan mengenai wawasan digital secara aplikatif. Pembicara memberikan informasi serta mendemonstrasikan beragam platform online yang bisa dimanfaatkan dalam proses pembelajaran online learning. Webinar ini menyadarkan para pendidik untuk bisa mengikuti perkembangan digital dan mempelajarinya dalam mendesain pembelajaran menarik di dalam kelas daring pada masa pandemi ini. Webinar kedua ini diikuti oleh 186 peserta. Berdasarkan hasil evaluasi yang telah diisi, sebanyak $71,1 \%$ dari peserta berpendapat bahwa isi materi dari webinar yang diterima peserta sudah sangat baik. Lebih lanjut, terdapat $73,9 \%$ dari peserta merasa bahwa program webinar sudah tepat sasaran. Berikutnya, terdapat $78,2 \%$ dari peserta yang menyatakan bahwa pembicara telah menguasai 
dan menyampaikan materi yang dibawakan dengan sangat baik dan sebanyak $95.8 \%$ peserta juga setuju bahwa pembicara dapat menyampaikan materinya dengan melakukan pendekatan secara teori simulasi, serta solusi yang relevan dan aplikatif. Tidak hanya itu, setelah mengikuti webinar kedua ini, sebanyak $71.1 \%$ peserta akan mengaplikasikannya ke dalam kehidupan sehari-hari. Selain itu, sebanyak $70.7 \%$ peserta juga setuju bahwa Moderator, MC, dan Panitia dapat memandu dan mempersiapkan acara dengan baik. Dengan demikian, webinar kedua berjalan dengan baik dan menjawab solusi permasalahan mitra.

Webinar ketiga dilaksanakan pada hari Sabtu, 8 Mei 2021 pukul 10.00 - 12.00 WIB dengan judul "Teaching and Learning English for Educators: The Strategies and The Apps". Webinar ini bertujuan untuk memberikan edukasi kepada guru, penggiat pendidikan dan masyarakat luas lainnya mengenai strategi-strategi yang dapat dilakukan untuk belajar dan juga mengajar Bahasa Inggris. Pada webinar ini pembicara memberikan informasi mengenai aplikasi-aplikasi digital yang dapat digunakan oleh guru untuk membantu proses pembelajaran Bahasa Inggris, dan juga membahas mengenai strategi belajar Bahasa Inggris untuk orang dewasa. Webinar ini dihadiri oleh 272 peserta. Berdasarkan hasil evaluasi yang telah diisi, sebanyak $68.3 \%$ dari peserta berpendapat bahwa isi materi dari webinar yang diterima peserta sudah sangat baik. Lebih lanjut, terdapat $62.6 \%$ dari peserta merasa bahwa program webinar sudah tepat sasaran. Berikutnya, terdapat $72.2 \%$ dari peserta yang menyatakan bahwa pembicara telah menguasai dan menyampaikan materi yang dibawakan dengan sangat baik, sebanyak $63.9 \%$ peserta juga menyatakan bahwa pembicara dapat menyampaikan materinya dengan melakukan pendekatan teori, serta solusi yang relevan dan aplikatif terhadap peserta. Tidak hanya itu, sebanyak $70 \%$ peserta akan segera mengaplikasikan setiap materi yang didapatkan ke dalam kehidupan mereka sehari-hari. Terdapat $62.7 \%$ peserta juga yang berpendapat bahwa Moderator dan MC dapat memandu acara serta setiap panitia yang bertugas dapat mempersiapkan webinar dengan baik dan lancar. Dengan demikian, webinar ketiga berjalan dengan cukup baik dan menjawab solusi permasalahan mitra.

Webinar keempat dilaksanakan pada hari Sabtu, 5 Juni 2021 pukul 19.00 - 20.30 WIB dengan judul "A Responsive Classroom Management: Responding to Student's Behavior". serta diikuti oleh 120 orang peserta. Melalui webinar ini, peserta diajak untuk belajar mengenai bagaimana menanggapi perilaku siswa dengan pendekatan yang responsif. Selanjutnya, menjadi seorang guru yang responsif, perlu memiliki tujuan untuk menciptakan kelas yang teratur, kontrol dan disiplin diri, mengajarkan tanggung jawab dan demokrasi, dan membangun relasi yang sehat. berdasarkan hasil evaluasi yang telah diisi peserta, didapatkan data sebanyak $91,3 \%$ peserta berpendapat bahwa pembicara sangat menguasai materi, dan $88.5 \%$ peserta juga setuju bahwa pembicara dapat menyampaikan materinya dengan melakukan pendekatan teori, simulasi, serta solusi yang relevan dan aplikatif. Selain itu, 89,4\% peserta berpendapat bahwa materi dari webinar ini sudah sangat baik. Kemudian mengenai ketepatan sasaran dari webinar yang kelompok lakukan, sebanyak $80,8 \%$ peserta berpendapat bahwa ketepatan sasaran sudah sangat baik. Tidak hanya itu, sebesar $82.7 \%$ partisipan juga setuju untuk dapat mengaplikasikan materi yang mereka dapatkan ke dalam kehidupan mereka sehari-hari. Setiap Moderator, MC, dan Panitia yang bertugas, peserta memberikan feedback yang cukup baik terkait cara memandu acara dan mempersiapkan webinar ini, dengan persentase sebesar $81.4 \%$ peserta. Dengan demikian, webinar keempat berjalan dengan baik dan menjawab solusi permasalahan mitra.

Webinar kelima dilaksanakan pada hari Jumat, 18 Juni 2021 pukul 19.00-20.30 WIB dengan judul "Merdeka Literasi" yang bertujuan untuk memberikan berbagai informasi dan solusi bagi para guru, penggiat pendidikan, dan masyarakat luas lainnya. Webinar "Merdeka Literasi" ini dikemas dalam bentuk talkshow. Webinar ini dihadiri oleh 306 peserta. Melalui webinar ini, pembicara mengedukasi peserta untuk mengerti pentingnya literasi serta bagaimana cara menanamkan hal tersebut kepada diri sendiri dan orang lain. Berdasarkan hasil evaluasi yang telah diisi, sebanyak $71,1 \%$ dari peserta berpendapat bahwa isi 
materi dari talkshow yang diterima peserta sudah sangat baik. Lebih lanjut, terdapat $66 \%$ dari peserta merasa bahwa program talkshow sudah tepat sasaran. Berikutnya, terdapat $74,3 \%$ dari peserta yang menyatakan bahwa pembicara telah menguasai dan menyampaikan materi yang dibawakan dengan sangat baik dan sebesar $68.1 \%$ peserta berpendapat bahwa dalam penyampaian materinya, pembicara dapat melakukan pendekatan secara teori, simulasi, dan solusi yang relevan serta aplikatif. Tidak hanya sebatas materi teori yang peserta dapatkan, tetapi sebanyak $72.3 \%$ peserta dapat memahami bagaimana cara menanggapi setiap perilaku siswa menggunakan reward serta punishment. Kemampuan Moderator dan MC dalam memandu acara juga bagi peserta sudah cukup baik, serta setiap panitia yang bertugas pun sudah sangat baik dalam mempersiapkan kegiatan webinar ini dengan persentase sebesar $71.2 \%$ peserta yang memberikan feedback nya. ,Melalui hasil yang didapatkan, dapat disimpulkan bahwa panitia telah berhasil menjalankan talkshow dengan baik dan menjawab solusi permasalahan mitra.

Selain memberikan materi pembelajaran bagi pendidik, panitia memotivasi peserta dengan membagikan hadiah buku yang bermanfaat tentang pendidikan. Pembagian buku sebanyak 3 sd 4 buku per webinar. Pembagian 23 buku tersebut berjudul sebagai berikut; Perencanaan \& Keuangan Pendidikan (Education and Finance Plan), Kampus Merdeka Seri 2: Tantangan COVID-19 Terhadap Implementasi Kampus Merdeka, Perencanaan Keuangan Keluarga, Kepemimpinan Pendidikan, IPA untuk PGSD/PGMI, Matematika untuk PGSD/PGMI, Buku Ajar Komputer dan Media Pembelajaran, Menjadi Guru itu Mengasyikkan!, Perencanaan Pembelajaran, Buku Doa Terbaik untuk Ibu, Buku Metode Pembelajaran Berbasis Sentra, Belajar Komputer, Internet, dan Media Sosial, Kurikulum untuk kehidupan, Sekolah untuk Kehidupan, Mutiara hati sang guru, Guru untuk kehidupan, Teach me to learn: Sebuah Implikasi dari Teori Pengajaran dan Pembelajaran UPH Press 2017, Kurikulum Bagi Pemula: Tinjauan Teoritis dan Aplikasi 2018, Kurikulum Bagi Pemula: Tinjauan Teori dan Aplikasi Dalam Perspektif Kristiani GMB-Indonesia 2019, Metodologi Penelitian Pendidikan, Pengembangan dan Penilaian Karakter Dalam Pembelajaran Tematik SD Book
Chapter 2020, Metodologi Penelitian PGSD/PGMI 2020 Nuta Media dan Book Chapter: Catatan Pembelajaran Dosen di Masa Pandemi Covid - 19.

Seiring berjalannya webinar, $\mathrm{PkM}$ ini membantu yayasan selaku mitra kerjasama dalam pengembangan pojok baca anak. Bentuk bantuan yang diberikan berupa rak buku baca anak sebanyak 3 buah, alat edukasi bermain anak berupa balokbalok kayu dalam mengembangkan kemampuan psikomotorik anak dalam mengenal pembelajaran matematika sederhana, buku-buku bacaan menarik buat anak usia dini, dan banner publikasi yang memudahkan masyarakat sekitar mengetahui adanya pojok baca anak. Bantuan ini tidak hanya bertujuan untuk memperlengkapi setiap fasilitas pengembangan di pojok baca, tetapi dengan adanya bantuan yang diberikan dapat dimanfaatkan untuk membantu setiap anak-anak yang membutuhkan sarana pendidikan sederhana, dan membantu setiap anak-anak pula khususnya di generasi saat ini untuk dapat mengembangkan minat baca dan literasi mereka, lebih lanjutnya melalui pojok baca ini juga dapat memperlengkapi setiap anak-anak dengan pengetahuan dan wawasan yang lebih luas terhadap literasi dan pendidikan.

\section{KESIMPULAN}

Kegiatan pengabdian kepada masyarakat melalui 5 kali webinar ini mampu memberikan kontribusi langsung bagi pendidikan Indonesia melalui desain materi pembelajaran yang menarik dan inovatif dari pembicara dalam peningkatan kompetensi pendidik. Berdasarkan setiap feedback yang diberikan oleh para peserta, rangkaian webinar ini sudah cukup baik untuk memperlengkapi setiap tenaga pendidik dan orang tua yang turut serta terlibat di dalam melakukan setiap perannya untuk kemajuan pendidikan Indonesia. Selain itu, tidak hanya sebatas teori yang peserta dapatkan, tetapi lebih lanjutnya dapat memberikan insight dan pengalaman yang baru untuk setiap tenaga pendidik serta orangtua agar dapat mengembangkan kreativitas, dan meningkatkan keterampilan di dalam lingkungan pendidikan Indonesia, dan mendukung setiap hal baik yang anak lakukan. Kemudian, pengembangan perpustakaan sekolah yang sekaligus dijadikan pojok baca anak usia dini di sekitar sekolah pada lembaga mitra mampu 
menumbuhkan minat baca anak secara luring seperti buku-buku cerita, rak buku, alat edukasi/media permainan. Pengembangan program ini perlu dilakukan sebagai kelanjutan untuk kegiatan PkM mendatang.

\section{UCAPAN TERIMAKASIH}

Atas berjalannya setiap rangkaian webinar yang telah dilakukan, kami mengucapkan terima kasih kepada;

1. Yayasan Shine Tiara Veritas, yaitu Ibu Rumondang sebagai penanggung jawab.

2. LPPM UPH yang telah ikut serta mendukung kegiatan PkM ini.

3. Service Learning - Student Life UPH sebagai gerakan awal kerjasama dengan Yayasan Shine Tiara Veritas untuk PkM.

4. Para pembicara, yaitu Webinar pertama; Bapak Imanuel dan Ibu Hernawati. Webinar kedua; Bapak Wiputra yang didamping mahasiswa binaannya Yonathan, Wahyunita, Steven, Martina, Nurlina, Agustina. Webinar ketiga; Bapak Michael dan Ibu Meicky. Webinar keempat; Ibu Keren dan Ibu Keren. Webinar kelima; Bapak Zulfikri, Bapak Wiputra dan Ibu Grace.

5. Fakultas Ilmu Pendidikan - Teachers College UPH dan Fakultas Psikologi, secara khusus mahasiswa yang terlibat, yaitu Klarissa, Aldo, Andreas, Dinda, Febri, Grace, Helen, Marvelia, Rachel, Carina, Chrystle, Ernita, Greys, Janice, Phutri, Ribka, Angeline, Febe, Hanna, Leonita, Shinta, Suci, Tesalonika, Vinny, Benedicta, Calista, Anandha, Joia, Veronika, Krismawati, Priscilla, Ester, dan Maria, Gresiana , Betania, Dewi, Efrani, Grace, Melania, Nadea, Paska, Pintariani, Tifara yang telah ikut serta membantu dalam pelaksanaan kegiatan rangkaian webinar ini.

\section{REFERENSI}

Amka. (2019). Filsafat Pendidikan. Sidoarjo: Nizamia Learning Center.

Brummelen. (2009). Berjalan Dengan Tuhan di Dalam Kelas. Jakarta: Universitas Pelita Harapan Press.

Budingsih, A. (2005). Belajar dan Pembelajaran. Jakarta: PT Rineka Cipta.

Dahan, RatnaWilis. (2011). Teori-teori Belajar dan Pembelajaran. Bandung: Erlangga.

Daryanto. 2009. Panduan Proses Pembelajaran. Jakarta: Publisher.

Gasong, D. (2018). Belajar dan Pembelajaran (P. Deepublish, ed.). Yogyakarta.

Knight, G. (2009). Filsafat dan Pendidikan. Jakarta: Universitas Pelita Harapan Press.

Kuntarto, E. 2017. Keefektifan Model Pembelajaran Daring dalam Perkuliahan Bahasa Indonesia di Perguruan Tinggi. Indonesian Language Education and Literature, 3(1), 99-110. 10.24235/ileal.v3i1.1820.

Kusmaryono, H., \& Setiawati, R. (2013). Penerapan Inquiry Based Learning Untuk Mengetahui Respon Belajar Siswa pada Materi Konsep dan Pengelolaan Koperasi. Jurnal Pendidikan Ekonomi DInamika Pendidikan, 8, 133-145.

Menteri Pendidikan. (2020). Surat Edaran Nomor 3 Tahun 2020 Tentang Pelaksanaan Pendidikan dalam Masa Darurat CoronaVirus (COVID-19).

Pangondian, R. A., Santosa, P. I., \& Nugroho, E. (2019). Faktor-Faktor Yang Mempengaruhi Kesuksesan Pembelajaran Daring Dalam Revolusi Industri 4.0. In Seminar Nasional Teknologi Komputer \& Sains (SAINTEKS) (Vol. 1, No. 1).

Setyotini, Sukswo, S. (2011). Penerapan Model Problem Based Learning Untuk Meningkatkan Kemampuan Berpikir 
Kritis Siswa SMP. Jurnal Pendidikan Fisika Indonesia, 7, 52-56.

Yanti, O. (2020). Usaha Kepala Sekolah dalam Meningkatkan Krativitas Guru dalam Pembelajaran di Sekolah Dasar. Jurnal Bahana Manajemen Pendidikan, 2, 808831. 